\title{
Neither Seen nor Heard: Compound Deprivation among Stateless Children
}

\author{
Brad K. Blitz
}

The plight of stateless children has not drawn the interest of many academics, human-rights activists, or policy makers. With the exception of Refugees International and the joint campaigns by Plan International, the United Nations Children Fund (UNICEF), and their associated partners to promote birth registration, the rights of children to a name, an identity, and a nationality are among the least charted aspects of humanrights advocacy and social scientific work in statelessness. Most of what has been published in this area has failed to single out the right to nationality and to acknowledge statelessness (which has its own definition under international law) in the context of children. ${ }^{1}$ This omission is particularly glaring when one considers that although the 1954 Convention Relating to the Status of Stateless Persons (hereafter 1954 Statelessness Convention) and the 1961 Convention on the Reduction of Statelessness (hereafter 1961 Statelessness Convention) have failed to garner much international support, the rights of children have been codified in the most widely ratified international legal instrument- the United Nations (UN) Convention on the Rights of the Child (CRC).

This chapter reviews the status of children under international humanrights law and examines how they are affected by statelessness. It argues that the human rights of stateless children are especially undermined by the degree to which states absolve themselves of their responsibility to protect children and examines two modes of state behavior that put children at risk. First, it considers the withdrawal of power and the consequences that arise when states refuse to protect children deemed outside the polity. Second, it examines how children's lives are affected by the direct violation of their rights by the state. The chapter begins with an analysis of the rights of stateless children under international law and follows with illustrations of how stateless children are affected by state actions in Europe (Slovenia and the United Kingdom), Africa 
(Democratic Republic of the Congo), and Asia (Myanmar). It concludes with a series of recommendations for enhancing protection.

\section{Stateless Children under International Law}

Under international law, all people (including children) are guaranteed protection of their human rights, irrespective of their nationality status. The UN Charter, Universal Declaration of Human Rights (UDHR), and subsequent documents speak of "all people"—not "nationals" or "citizens"- as the basis for enjoyment of human rights. In the context of stateless minorities, the situation is no different: persons belonging to minority groups equally enjoy human rights, irrespective of their nationality status. This is noted in article 27 of the 1966 International Covenant on Civil and Political Rights (ICCPR) and the very similar article 30 in the CRC. The rights of minorities are especially elaborated over the entirety of the 1965 Convention on the Elimination of All Forms of Racial Discrimination (CERD). In practice, however, governments often use nationality and citizenship status to restrict access to state resources, a strategy that introduces the danger of discriminatory treatment against nonnationals. The rights of all are not uniformly respected.

Although citizenship is frequently defined in national legislation, within international law citizenship has generally been understood in the context of nationality. A substantial body of international jurisprudence establishes that nationality laws must be consistent with general principles of international law as noted in the 1923 decision by the Permanent Court of International Justice ${ }^{2}$ and under article 1 of the 1930 Hague Convention on Certain Questions Relating to the Conflict of Nationality Laws. ${ }^{3}$ Within the UN system, nationality is situated unequivocally within the framework of universal human rights. Article 15 of the UDHR recognizes that nationality ensures individuals access to the enjoyment of human rights and prohibits the arbitrary removal of this right. ${ }^{4}$ Although the UDHR does not itself specify what constitutes arbitrary deprivation, accepted definitions of arbitrariness usefully describe the limitations placed on states. Arbitrariness covers practices that do not follow a fair procedure or due process, and the term is used to refer to actions where states cannot be held to account. ${ }^{5}$

While it is accepted that states may withdraw citizenship rights under certain conditions, provided they are reasonable and meet the test of nonarbitrariness, in general such conditions do not apply to children. ${ }^{6}$ Article 15 of the UDHR establishes several principles that reaffirm the 
centrality of universal protection and also guard against the forced assimilation of children of minorities. ${ }^{7}$ These provisions are reinforced by subsequent articles that are of direct relevance to children. For example, article 25(1) states in subsection (1) that "Everyone has the right to a standard of living adequate for the health and well-being of himself and of his family, including food, clothing, housing and medical care and necessary social services" and in subsection (2) that "Motherhood and childhood are entitled to special care and assistance." Finally, the UDHR includes rights to education under article 26. Thus, irrespective of states' rights to determine the criteria for nationality, international law stipulates that stateless children should enjoy a host of rights irrespective of their nationality status.

The ICCPR restates the principle of universal coverage, includes protections against arbitrary expulsion (article 13) and equality before law (article 26), and further sets out obligations to prevent the denial of citizenship by insisting on birth registration and reaffirming a child's right to nationality under articles 24(2) and (3). Also noteworthy is the introduction of article 27 on minority rights, which may be taken to prohibit both the forced assimilation of children ${ }^{8}$ and the denial of citizenship on arbitrarily defined grounds that relate to linguistic and cultural backgrounds. ${ }^{9}$ The related 1966 International Covenant on Economic, Social, and Cultural Rights (ICESCR) explicitly prohibits the creation of conditions that undermine the social and economic survival of an individual and their family members and specifically sets out principles to protect children. ${ }^{10}$ Under article 10(3), children and young persons are to be protected from economic and social exploitation. Further, under article 13(2), the Convention sets out the universal right of access and entitlement to free primary education.

Most important for the purposes of this chapter is the CRC, which restates the universal protections and provisions on matters of nationality and elaborates on the rights of children. Under article 7(1), the CRC declares that every child has a right to acquire a name and nationality and stipulates that states should register births to ensure that this happens. Under article 7(2), it draws attention to the prospect of statelessness in the event that births are not recorded and nationality not formally transmitted. The CRC also introduces a clause regarding unlawful interference that firms up the principle of arbitrariness described above. Under article $8(1)$, it declares that "States Parties undertake to respect the right of the child to preserve his or her identity, including nationality, name and family relations as recognized by law without unlawful interference." 
It also mentions the possible deprivation of elements of a child's identity and calls on states to reestablish a child's identity in such cases under article $8(2)$. This clause may be taken to extend the prohibition on the deprivation of citizenship, given the essential relationship between citizenship and personal identity. These clauses in the CRC add further weight to claims regarding the prohibition of arbitrary denial and deprivation of citizenship toward children, not least because this instrument has been ratified by almost every state.

Finally, other international conventions further reaffirm the principle of universal protection and include other groups, among them women and children. ${ }^{11}$ The 1990 International Convention on the Protection of the Rights of All Migrant Workers and Members of Their Families (hereafter Migrant Rights Convention) also reiterates the principle of universal protection. Although only thirty-five states have signed onto this convention, it is significant because it acknowledges the role that the migration of workers plays in the global economy and is directly relevant to the concepts of de facto and effectively stateless people, as set out in the introduction to this volume.

\section{Nondiscrimination and the Rights of Children}

A significant body of international law has elaborated the principle of nondiscrimination on the basis of race, ethnicity, and related criteria that further limit state action and includes provisions regarding the rights of children to nationality. These include the CERD, the 1979 Convention on the Elimination of All Forms of Discrimination against Women (CEDAW), the 1992 Declaration on the Rights of Persons Belonging to National or Ethnic, Religious and Linguistic Minorities, and the 1990 Migrant Rights Convention.

One of the most noteworthy instruments is the CERD. Article 1 of the CERD provides a precise definition of racial discrimination and is particularly relevant to the problem of denial or deprivation of citizenship to children because it addresses the issue of motivation and also highlights the liabilities of states that create conditions that exacerbate the vulnerability of minority populations. The CERD affirms that differential treatment between groups of noncitizens may constitute discrimination $^{12}$ and reaffirms under article 5 the universal provision that state parties are obliged to guarantee equality for all in the enjoyment of civil, political, economic, social, and cultural rights to the extent recognized under international law. 
In 2004, the Committee on the Elimination of Racial Discrimination (hereafter the Committee) published its General Recommendation Number 30 on the theme of discrimination against noncitizens. In this document, the Committee reaffirmed the need to tighten loopholes that might lead to discrimination on the basis of citizenship and nationality. This recommendation called on states to take measures to ensure that noncitizens enjoyed protection before the law; had access to education, housing, employment, and health; and were protected against forced expulsions. It further sought to clarify the prohibitions regulating states under international law. Under section IV, it recommended that states "pay due attention to possible barriers to naturalization that may exist for long-term or permanent residents" and called on states to reduce statelessness among children by, for example, encouraging their parents to apply for citizenship on their behalf and allowing both parents to transmit their citizenship to their children. ${ }^{13}$ The Committee has generated an important body of country-specific recommendations on the issue of discrimination in relation to the acquisition of citizenship, some of which make explicit reference to children. For example, the Committee called on Mauritania to respect the principle of nondiscrimination in children's access to nationality. ${ }^{14}$

The denial or deprivation of citizenship is also prohibited under the 1954 Statelessness Convention and the 1961 Statelessness Convention. Although these conventions have not been ratified by large numbers of states, they have made a significant contribution to the human-rights regime regarding the treatment of noncitizens. For example, the 1954 Convention provides for equality of treatment under articles 7 and 8 . Otherwise, this instrument puts stateless persons on an equal footing with noncitizens residing in the country. Under articles 20 through 24, the 1954 Statelessness Convention includes provisions that cover children by calling on states to treat stateless persons no less favorably than nationals with respect to rationing, housing, public education, public relief, and social security.

In addition to these UN conventions, a growing body of regional treaties and conventions has called attention to the principle of nondiscrimination and equal treatment of noncitizens, including children. For example, in the context of Africa, the 1981 African Charter on Human and People's Rights includes several articles that apply the principles of nondiscrimination, equality before the law, and the rights of equal access. Together these articles severely restrict the conditions under which nationality may be denied. 
The 1999 African Charter on the Rights and Welfare of the Child has been ratified by only a small number of states, but it contains additional provisions that seek to protect children from some of the consequences associated with the arbitrary denial of citizenship and the vulnerability that such practices create. The charter aims to protect the private life of the child and safeguard the child against all forms of economic exploitation and against work that is hazardous, interferes with the child's education, or compromises his or her health or physical, social, mental, spiritual, and moral development.

Within the European system, a number of central conventions and related instruments have been introduced that prohibit the denial and deprivation of citizenship and significantly advance international jurisprudence in this area. The most important sources of law on this region include the 1950 European Convention for the Protection of Human Rights and Fundamental Freedoms (hereafter the European Convention) and its five protocols, corresponding rulings from the European Court of Human Rights, and the Consolidated Treaties of the European Union. The European Convention is the only international human-rights agreement providing such a high degree of individual protection. The European Convention contains several provisions that constrain states' actions to deny or deprive eligible individuals of the right to citizenship including article 14, which sets out a universal prohibition against discrimination, and article 17, which prohibits the abuse of rights. The 1963 European Convention on the Reduction of Cases of Multiple Nationality and on Military Obligations in Cases of Multiple Nationality establishes rules to reduce multiple nationalities in the case of the acquisition or renunciation of a nationality. It also addresses the legal consequences of loss of nationality for persons concerned, including children.

Most important is the 1997 European Convention on Nationality (hereafter European Nationality Convention). The main principles of this Convention are the prevention of statelessness, nondiscrimination in questions of nationality, as well as nondiscrimination in matters of sex, religion, race, color, national, or ethnic origin. The European Nationality Convention also calls for respect for the rights of persons "habitually resident" on the territories concerned and thus may apply to individuals who, in the terminology adopted in this study, are defined as effectively stateless. In the context of post-cold war Europe, the European Nationality Convention also establishes principles concerning persons in danger of becoming stateless as a result of state succession. One of the most significant expressions of concern about the arbitrary denial of citizen- 
ship is found in the brief article 4 , which sets out the rules on nationality and guiding principles, including that (1) everyone has the right to a nationality, (2) statelessness shall be avoided, (3) no one shall be arbitrarily deprived of his or her nationality, and (4) neither marriage, the dissolution of a marriage between a national of a state party and an alien nor the change of nationality by one of the spouses during marriage shall automatically affect the nationality of the other spouse. The 2006 European Convention on the Avoidance of Statelessness in Relation to State Succession also sets out important protections, including the granting of citizenship to all who had it at the time of state succession, on condition of residence and historic connection.

Within the European Union (EU), the prohibition of discrimination on the basis of nationality is at the very heart of the Union and is recorded under article 12 of the 2006 EU Treaty. With the exception of immigration, there are ever fewer points of distinction between citizens and noncitizens living within the EU. Indeed, the EU is one arena where national identity and the privileges of citizenship have been notably disassociated. EU member states are required to permit the entry and residence of the family members of those citizens and to provide education for their children on the same basis as that of their own nationals' children.

A significant body of case law is emanating from national and regional courts and treaty bodies. One of the most widely cited is the case of Judge Unity Dow v. Attorney-General in Botswana. Dow, a distinguished human-rights activist, successfully challenged the legitimacy of the Citizenship Act, which denied Botswana citizenship to her children because her husband was a foreigner. The High Court and later the Court of Appeal found that the gender discrimination inherent within the Botswana Citizenship Act was in violation of the constitution. ${ }^{15}$

More recently, the prohibition on arbitrary deprivation and denial of citizenship to children has been reiterated by the Inter-American Court of Human Rights, which ruled that 'states' discretion must be limited by international human rights that exist to protect individuals against arbitrary state actions." In Dilcia Yean and Violeta Bosico v. Dominican Republic, the Inter-American Court concluded that the Dominican Republic's discriminatory application of nationality and birth-registration laws and regulations rendered children of Haitian descent stateless and unable to access other critical rights, such as the right to education, the right to recognition of juridical personality, the right to a name, and the right to equal protection before the law. In so doing, it affirmed the 
human right to nationality as the gateway to the equal enjoyment of all rights as civic members of a state. The ruling recognizes that statelessness makes impossible the recognition of a juridical personality and the enjoyment of civil and political rights and that it produces a condition of extreme vulnerability. It also affirms that states cannot base the denial of nationality to children on the immigration status of their parents and that the proof required by governments to establish that an individual was born on a state's territory must be reasonable.

\section{Statelessness in Context}

In spite of the substantial development of international law outlined above, children are particularly affected by statelessness. The denial of the right to nationality is often accompanied by a series of deprivations that have longstanding consequences in terms of children's social, economic, and personal development. In its most extreme form, the total exclusion of children from state services such as education and health care and the denial of the right to identity that may result from discriminatory policies can leave children vulnerable to the compound ills of poverty, infant mortality, chronic morbidity, and exploitation in the labor market, in the sex industry, and by organized criminals including human traffickers and armed gangs. The following section explores the effects of statelessness on the lives of children in three regional contexts.

\section{Europe}

Although the European region is the site of some of the world's most extensive laws prohibiting statelessness, European states have redefined their immigration laws and obligations under the international agreements noted above, including the 1951 Convention. As a result, several European states have contributed to the creation of a protection gap where people who have reached their shores in search of protection have been denied this right. In addition, the breakup of Yugoslavia and the former Soviet Union was followed by a reorganization that did not automatically give nationals of former federations the nationality of the independent states in which they were located. These two processes have left approximately half a million individuals-including former migrants and their descendants-effectively stateless. Although children should be among the most protected category of people in the EU, some have been denied the benefits and protections that come with nationality and that 
follow from the principle of nondiscrimination. Two contrasting cases are offered below. In the first case, the United Kingdom withdrew its powers to protect, and in the second, Slovenia undermined children's rights and ultimately removed them from its territory.

\section{United Kingdom}

It is difficult to estimate the number and profile of stateless children in the United Kingdom. Although the United Nations High Commissioner for Refugees (UNHCR) estimates that there were only 205 stateless people in the United Kingdom at the end of 2005, children tend to be treated as a separate category excluded from these figures. ${ }^{16}$ In practice, many refused child asylum seekers are (to use the terminology proposed by Jacqueline Bhabha in the introduction to this volume) de facto stateless, so the official stateless estimates represent a significant underestimate of the magnitude of the problem of statelessness among children in the United Kingdom. Recent research on the problem of refused asylum seekers in the United Kingdom has started to paint a harrowing picture of destitution and associated mental health problems. ${ }^{17}$ Further, as suggested by the Still Human Still Here Campaign initiated by refugee support organizations, destitution itself appears to be a means of forcing people to leave the UK.

Although the situations of stateless people and asylum seekers are legally distinct, the growing contraction of benefits and support to asylum seekers contributes to serious problems in the ways in which vulnerable populations access their human rights to educate their children, secure decent housing, and receive health care. ${ }^{18}$ A further consequence of recent policy measures has been the stigmatization of asylum seekers into categories of those "deserving" and "undeserving" protection, ${ }^{19}$ a fact equally relevant to stateless populations in general and children in particular.

One episode illustrates the coercive way in which UK immigration and asylum policies have been applied to the detriment of stateless children. In summer 2004, Thames Valley police officers and the UK immigration authorities arrested a number of declared Pakistani refugee families in Oxford as part of Operation Iowa. The incident led to a criminal trial and an immigration inquiry, which resulted in the cancellation of refugee status and subsequent withdrawal of state protection that had been given to a group of stateless children. The families concerned claimed to be not Pakistani but in fact Kashmiri, their nationality status having been disputed by the British, Indian, and Pakistani governments. 
Although Kashmiris born in India are entitled to the same rights as citizens, India has consistently denied citizenship to Punjabi Muslims who have been living in Kashmir for more than sixty years. The situation has been further complicated by the geography of Kashmir and the history of conflict in the region. India reportedly amended its Citizenship Act of 1955 and Citizen Rule of 1965, authorizing the district magistrate of Jaisalmer to grant Indian citizenship to Pakistanis who had been living in the border district for the last five years. This effort was aimed at some of the Kashmiri Pandits who represented approximately 12 percent of the population in the valley in 1947 but since 1989 have been expelled (as many as 300,000 families have been forced out). In 2003, the Ministry of Home Affairs asked states to provide identity cards to displaced Kashmiri Pandits to regularize the situation of at least 50,000 displaced persons who were not registered as migrants when they left the Kashmir Valley after 1990. However, for over 100,000 Punjabi refugees who fled to Jammu and Kashmir from neighboring Sialkot district of Punjab province (now in Pakistan) in 1947, both they and their descendants have been denied the right to citizenship in India, and their exclusion has been a source of recent protests and unrest. ${ }^{20}$

The refugees who settled in Oxford claimed to be from Kashmir, although they had ties to Pakistan and their ancestral home was described to the author as Sialkot. Yet their nationality status became an academic matter following police Operation Iowa, which brought the families to court and began a process whereby their right to remain in the United Kingdom was called into question. In the 2005 criminal case R. v. Faruq and Others (Operation Iowa), the Crown Prosecution Service claimed that there had been a conspiracy to contravene the Immigration Act by bringing relatives into the UK under false pretenses and then falsely claiming asylum as a prelude to falsely claiming benefits from government departments and local authorities. As a result of this criminal hearing, the Home Office revoked the status of several of the parties concerned, including the children of the families involved in the criminal act. It was argued that if the families had lied during their asylum application, then other information could no longer be considered credible, including the ages of some of the children.

Interviews conducted in winter 2008 with some of the older children of family members revealed the extent to which the governmental action undermined their well-being and personal identity. One nineteen-yearold who was allowed to continue his further education studies because he enrolled before the 2004 Immigration Act came into effect claimed that his home life was dominated by arguments. As a consequence of his 
unhappy domestic environment, he spent time "on the streets, hanging around parks, fighting and in trouble" and claimed that he would not have done so if he had been permitted to work. He said that he currently spent most of his time playing computer games and was otherwise idle. He noted that as a result of his lack of documentation, he was unable to drive, open a bank account, obtain a mobile phone contract, or go to clubs like other young people. His friend described a similar situation and explained how the loss of his identity card (ID) card and cancellation of his refugee status in 2004 affected his life:

Without ID, you can't do anything. You can’t get anything. I used to get $£ 30$ from Social Services, but this stopped when I was 18. They said I have to work, but I said I couldn't. They said, "It's not our problem."

He then described his life as a stateless person in the UK:

I can't work because of paperwork. I can't go to different countries. I tried [to work] in a restaurant, but I couldn't. If papers arrived, I would be like normal people. They can do whatever they want. I think there is something missing. I don't have my ID to prove who I am. Sometimes I question that. My identity is missing. Everyone has their identity.

By the end of 2009, the plight of the two Kashmiri interviewees remained unchanged. Both were still without status and existed precariously by depending on charitable organizations and the good will of professionals in the absence of state protection.

\section{Slovenia}

With the creation of the independent state of Slovenia in 1991, its government was faced with the task of defining formal citizenship policies. Ethnic Slovenes were to receive citizenship on the basis of jus sanguinis, which effectively meant the transfer of Slovenian nationality under the former Yugoslav system. Under the principle of jus soli, nonethnic Slovenes who were considered autochthonous minorities were allowed to naturalize if they were born on the territory. The remaining issue to be resolved concerned the 221,321 foreigners who could not be classified as either ethnic Slovenes or recognized minorities.

Prior to independence, there were many indications that Slovenia's secession from the Federal Republic of Yugoslavia would be met with protection arrangements for nonethnic Slovenes who were not covered by the existing constitutional provisions given to the autochthonous minorities from the Hungarian and Italian communities. ${ }^{21}$ One means of protection was the offer of citizenship to all foreigners who had resided permanently on Slovenian soil at the time of the plebiscite. To this end, 
the Act Governing Citizenship was introduced in June 1991 providing the nonautochthonous minorities with the opportunity of naturalization. According to article 40, former Yugoslav nationals who were resident on the territory of Slovenia could apply to naturalize but were restricted to a six-month period. More than 170,000 were granted citizenship in this way, but thousands of others who either did not know about the law or who simply failed to apply were denied status. At this point, more than 25,000 Slovenian residents were disenfranchised, and the policy known as the erasure began.

In February 1992, article 81 of the Aliens Act came into force and designated new categories of noncitizens. In effect, all those who had been registered by means of the Aliens Act were deregistered and lost their residency rights and the social and economic privileges that came with residency status. The erased included a wide range of individuals with different histories-approximately five hundred officers from the Yugoslav National Army (JNA), many of whom had never participated in active service and had intermarried with Slovenes; Bosniaks, Croats, Serbs, and Roma who had migrated to Slovenia for work (especially in the mines); and civilians born in Slovenia whose birth had been registered in one of the other republics. The only unifying factor was that these individuals were perceived as southerners and thus exogenous to the Slovene nation. ${ }^{22}$

As evidenced by the documents now released by the Ministry of the Interior, there was a concerted effort to ignore the acquired rights of the residents who became erased. ${ }^{23}$ Hence, the blame for the erasure must lie with the Slovenian government of the time. Residents were asked to present their documents to state agencies and appear before the town hall or local administrative unit. According to Jasminka Dedic, Vlasta Jalušic, and Jelka Zorn, ${ }^{24}$ there was considerable uniformity of practice. Official authorities notified residents to appear in person, at which point their documents were often confiscated or destroyed-punched, defaced, cut up-in front of them. Those who lost their residency status became official foreigners-effectively stateless persons who automatically lost access to the social and political privileges they had enjoyed for decades. ${ }^{25}$ The cancellation of their status left them especially vulnerable.

Several of the erased were subject to arbitrary removal and were deported from Slovenia. ${ }^{26}$ One estimate is that approximately twenty people were expelled. ${ }^{27}$ The Helsinki Monitor, a quarterly on security and cooperation in Europe, contends that the number is far greater and that people were handcuffed and transported to Croatia, Macedonia, 
and Montenegro by bus, plane, and ferry, respectively, without the knowledge of the destination states. ${ }^{28}$ The expulsions also affected children and those who had just reached the age of majority.

The erasure broke up families and separated parents from their children. ${ }^{29}$ Those who were able to work in Slovenia claimed that their lack of status made them liable to exploitation and subject to intensive and family-unfriendly work schedules. One participant explained that during the period when he was erased, he could not afford to be ill and could visit his child only once every two weeks. He did not have time for family, charging "they made mental invalids of us. I worked for 350 hours a month driving a taxi." 30

One family of Bosnian refugees explained how their children had been removed from Slovenia at the insistence of the state, in spite of their refugee status and long-standing connection to Slovenia. ${ }^{31}$ The daughter was born in Doboj, Bosnia, in 1980, and the father began working in mines in Slovenia in 1981. When the wife came to Slovenia in 1992 with their three children (age twelve, ten, and two and a half) as refugees, the father had temporary residency, and the wife and children received a residence permit. In 1995, the father filed papers for permanent residency but was turned down by the ministry because it was found that he had been outside the country for thirteen days. Officially, the five family members were refugees from 1992 to 1996, when the father received permanent residency. He received Slovene citizenship in 2002.

From 1992 to 1998, his daughter lived with the family in Valenje, Slovenia, on the basis of temporary residency. In January 1998, her father sought to extend her residency but was told that this would not be possible because she would turn eighteen in two months (March 1998) and would have to leave the country at that time. A few days before her birthday, as instructed, he took her back to Bosnia where she stayed with a family in Gracanica. The Slovene government merely gave her notice that she could return in 2001. Since 1998 the daughter has been able to visit her family in Slovenia on one-month tourist visas. Although the family became Slovene citizens in 2004, the daughter has been repeatedly refused a temporary residence permit.

In another case, a woman who was erased with her daughter explained how the erasure and the abuse she suffered at the hands of the state affected her family life and children. ${ }^{32}$ In 1992, she placed her older daughter, who was mentally ill, in a special daycare unit. The costs were enormous, and her Bosnian father therefore offered to take the child with him to Bosnia and then send her to a relative in Germany. However, the 
war in Bosnia interrupted the family's plans, making it impossible to leave Bosnia until 1995. After the war ended in 1995, the woman brought her daughter back to Slovenia, where she unsuccessfully tried to obtain documents to enroll her child in school. Slovenian officials told her that if she herself had no documents, then the child could not obtain any either. Since 1996, the daughter has been living in Bosnia, unable to rejoin her mother.

\section{Africa: Democratic Republic of the Congo}

The conflicts in the Democratic Republic of the Congo have multiple sources, but one relates to the problem of statelessness-particularly the denial and deprivation of citizenship to the ethnic-Rwandan members of the Banyamulenge community. Although the Banyamulenge arrived in the territory of what is now the Democratic Republic of the Congo from Rwanda centuries ago, they have often been excluded from full participation in the country. At issue is the nature of Congolese identity. Some crucial markers are 1885, when King Leopold II of Belgium made the region his personal property; 1908, when the Belgium parliament took over the region as a colony; and 1960, when the country achieved independence. ${ }^{33}$

It is generally accepted that the Banyamulenge settled in the Mulenge hills between the towns of Uvira and Bukavu in what is now South Kivu. Several thousand were also forcibly migrated and settled in the region by the Belgian colonial forces, which enlisted the Banyamulenge as forced laborers on rubber and agricultural plantations. Living in the border region, they have since been collectively identified with ethnic interests both internal and external to the Congolese state, which has repeatedly sought to exclude them from full membership, including access to state resources. The exclusion of the Banyumulenge is illustrated by the personal testimony that a seventeen-year-old boy, now in detention in Egypt, gave to the Equal Rights Trust: ${ }^{34}$

We were not wanted in Congo. The people on the street treated us as if we were not Congolese. They treated us as if we were foreigners. This is because we are Banyumulenge. All Banyumulenge people in Congo are treated this way. Like my parents, many Banyunulenge people are living without papers. My sister and I never got Congolese nationality. People were always telling us we were not real Congolese. My mother taught us at home because I was not allowed to go to a public school. The Congolese government used to tell us that if we wanted to study, we should go to where our grandfathers came from in Rwanda. ${ }^{35}$

Relations between the Congo's main ethnic groups grew strained during the period following independence, when the Banyamulenge were 
charged with helping the Congolese National Army crush a rebellion in the Kivu region in 1964. The rebellion had aimed to install a communist style of government in which property, land, and cattle were to be shared among the local people. In January 1972, Joseph Désiré Mobutu, the president of Zaire (the country was known as Zaire from 1971 to 1997), signed a decree collectively granting Zairian citizenship to all Rwandan and Burundian natives who had settled in Zaire prior to 1950. However, this decree was retroactively invalidated by the parliament in 1981, effectively rendering the people of Rwandan origin stateless.

Preparations for elections in 1991 included the completion of a census, which again raised the question of the rights of the Banyamulenge to full political participation. As Mobutu reexamined the composition of the Zairian state under the auspices of a new "sovereign national conference," the place of the Banyamulenge attracted further attention. Unfortunately for the Banyamulenge, they were ultimately excluded, again on the grounds that they were nonindigenous. A few years later, the genocide in Rwanda and unrest in Burundi quickly drew the Banyamulenge and then state of Zaire into the wider ethnic conflicts. During the Rwandan genocide in 1994, thousands of Banyamulenge crossed back to neighboring Rwanda and joined the Tutsi-led rebels (the Rwandan Patriotic Front) to topple the Hutu-dominated government there. The transnational nature of the conflict continued after the genocide. For over fifteen years, the Democratic Forces for the Liberation of Rwanda ${ }^{36}$ "preyed on Congolese civilians in the mountainous provinces of North and South Kivu," including children. ${ }^{37}$

In 1996, a local Zairian official warned all Banyamulenge that they must leave Zaire within a week and threatened to confiscate their property. Armed Banyamulenge repelled the Zairian offensive and were joined by rebel forces under the leadership of the future Zairian president, Laurent Kabila. The Banyamulenge were considered to have played an essential role in the overthrow of Mobutu, but their relationship with Kabila quickly eroded in 1998 when the new leader decided to expel Rwandan and Ugandan contingents from his army. In the name of defending Tutsis against oppression in North Kivu, a rebel army consisting primarily of Banyamulenge and commanded until recently by General Laurent Nkunda, has been fighting the DRC government. Despite a 2004 citizenship law granting citizenship to all those born on the territory that became the DRC, several hundred thousand of the Banyamulenge community have been unable to obtain nationality documents. As noted by the UK Home Office, "in practice, there are no examples of cases of Banyamulenge who have successfully obtained Congolese nationality." ${ }^{38}$ 
Nationality remains determined by ethnic criteria rather than birth on the territory, and the debate over those considered indigène or nonindigène continues at the expense of the Banyamulenge. ${ }^{39}$ The capture of Nkunda by joint Congolese and Rwandan forces in Operation Umoja Wetu in January 2009 did not quell the violence, which has left an estimated 900,000 displaced.

In this setting, children-many of whom have been denied nationality-have been affected as both civilians and combatants in the conflicts in eastern Congo. The place of children in conflict was taken up in the 1998 report by the UN Special Representative for Children and Armed Conflict, who denounced Kabila's recruitment of children and their enlistment in the military operations of the Alliance of Democratic Forces for the Liberation of Congo. Children as young as nine were used as Kadogos (runners), bodyguards for officers, water and ammunition carriers, and spies. By their early teens, children were fighting as fully fledged rebels on behalf of Kabila and his forces. Human-rights reports noted that many such children were later left destitute as street children in Kinshasa. ${ }^{40}$

Over the course of the renewed conflict over the past two years, the UN has repeatedly called on both the Congolese and Rwandan governments to respect the rights of children and to shield them from abuse and enlistment as child soldiers. ${ }^{41}$ Notwithstanding such calls, Human Rights Watch has recently documented the deliberate killing of children, the use of rape against children in North and South Kivu, and the continued recruitment of child soldiers as guides and porters. ${ }^{42}$ Children have also been victimized by the deliberate destruction of health facilities and schools. ${ }^{43}$

\section{Asia: The Rohingya in Bangladesh and Myanmar}

The plight of the Rohingya is part of a particularly sad chapter in the contemporary history of South Asian statelessness. The Rohingya are a Muslim ethnic minority from Myanmar (formerly called Burma) that has been subject to decades of repression. Approximately 800,000 Rohingya are now concentrated in the Arakan region (also known as Rakhine state) in western Myanmar, where they have been denied citizenship and are subject to killings, rape, and forced labor. Several hundred thousand have fled to Bangladesh, Thailand, Malaysia, and Indonesia, where they have also suffered serious human-rights violations and enjoy very limited protection from nongovernmental organizations (NGOs) and UNHCR. Although the denial of citizenship has made the Rohingya especially 
vulnerable to abuse by the state, given the isolationist nature of the current regime in Myanmar, this section focuses on the plight of stateless children in and outside of Myanmar and the challenges that they face regarding state protection.

The size of the population of Rohingya living outside Myanmar is not known. Hundreds of thousands were expelled in the 1960s by the military-socialist regime of General Ne Win during the "Burmese Way to Socialism" nationalization program. ${ }^{44}$ Amnesty International has documented the effects of subsequent expulsion campaigns, including the murderous "ethnic cleansing" campaign Operation Dragon King (Naga Min) that drove more than 200,000 Rohingya into Bangladesh in 1978. Unfortunately, their reception in Bangladesh has been less than positive since geopolitical factors have frustrated attempts to secure protection for the expelled Rohingya. Over three decades, the Bangladeshi government has withheld food aid, denied NGOs access to camps, and with the exception of a small minority of Rohingya, generally refused to recognize their rights as refugees. In the case of those expelled following Operation Dragon King, an estimated 10,000 died from starvation and disease, as a result of Bangladeshi governmental policies. ${ }^{45}$

Problems associated with their cancellation of citizenship status did not arise until 1983, however, when the Burmese government excluded Rohinhya from a national census. According to Amnesty International, "the 1982 Citizenship Act legalized this exclusion, creating two categories of people, full citizens of Burma, including most ethnic groups, and then 'associate' citizens, such as the South Asian and Chinese minorities. The government disqualified the Rohingya from either group because they could not prove their lineage as 'associates' before 1948." 46 The creation of stateless populations inside Myanmar precipitated a series of refugee crises and border conflicts with Bangladesh. In 1991, the Burmese army expelled more than 250,000 Rohingya, destroying villages and buildings on its way and forcing the Rohingya into two towns in southern Bangladesh-Teknaf and Cox's Bazaar.

Since the Rohingya's arrival in these two towns, the Bangladeshi authorities have shown little interest in the humanitarian problem. Thousands of refugees have been crammed into squalid refugee settlements, and only two of these (Kutupalong and Nayapara in Cox's Bazaar) have been designated official UNHCR-assisted refugee camps where residents can receive rations, health care, and education for their children. Although there are estimates of between 200,000 to 400,000 Rohingya in Bangladesh, only 29,000 have been given refugee status. ${ }^{47}$ Instead of offering 
protection, the Bangladeshi government has repeatedly engaged in repatriation drives, forcing the Rohingya refugees back over the border into Myanmar. In spite of some internationally mediated initiatives-including the signing of a formal Memorandum of Understanding between UNHCR and the Myanmar government in November 1993, which enabled UNHCR to establish a presence on the ground in Rakhine state-the repatriation initiatives conducted in collaboration with the Bangladeshi authorities have raised many questions about the forced nature of these returns. Others have challenged that these repatriation initiatives violate international human-rights laws. In 1995, the United Nations assisted the Bangladeshi government in a repatriation process characterized by excessive use of force, including killings perpetrated by the Bangladeshi security forces and also by the Burmese troops receiving the Rohingya. ${ }^{48}$

Although the Bangladeshi authorities have returned hundreds of thousands of Rohingya to Arakan state in Myanmar, new refugee movements continue unabated, fueled by the ongoing repression of the Rohingya in Myanmar. Unfortunately, recently arrived Rohingya refugees from Myanmar have been denied access to UNHCR-supported refugee camps in Cox's Bazaar because the Bangladeshi authorities have described new arrivals as "economic migrants." Furthermore, the Bangladeshi government has recently stepped up efforts to return large numbers of Rohingya in the wake of new conflicts over the 320 kilometer maritime border between Myanmar and Bangladesh. The latest conflict was exacerbated following an agreement between the government of Myanmar and South Korea's Daewoo International Corporation, which was granted oil and gas exploration rights in an area of contested waters. Since then, Bangladeshi border forces have expelled Rohingya living in the border area. Tensions worsened following the rejection of a repatriation plan by the Burmese junta in 2008 and the recent news that it had started construction of a 200 kilometer fence to prevent future "push backs" of Rohingya into Myanmar. ${ }^{49}$ One consequence of the tensions between Myanmar and Bangladesh over the maritime border has been an influx of Rohingya refugees to recognized camps, which has created a strain on resources. ${ }^{50}$ A recent decision by the European Commission on the financing of humanitarian assistance to Bangladesh noted that the numbers of Rohingya in Cox's Bazaar had increased dramatically in just one year as a result of the internal flows of Rohingya seeking safety: ${ }^{51}$

DG ECHO ${ }^{52}$ mission in September 2008 identified a spontaneous settlement of around 5,000 undocumented Rohingyas, living in very poor conditions, directly 
adjacent to Kutupalong UNHCR camp; a further DG ECHO mission in February 2009 observed that this spontaneous settlement had grown considerably; most of the inhabitants seem to have been expelled from Bangladeshi villages.

Recent humanitarian assessments carried out by DG ECHO partners between March and April 2009 revealed that there are now approximately 20,500 people in this spontaneous settlement and their living conditions have deteriorated: they have very basic shelters with no access to healthcare, sanitation or safe water, and are excluded from official camp services. ${ }^{53}$

Recent arrests by Bangladeshi forces have further discouraged Rohingya from leaving the relative safety of camps in search of work and food.

The problems facing stateless Rohingya children, a disproportionately large section of this refugee population, are especially daunting. Those outside of the handful of UNHCR refugee camps cannot access education and are subject to malnutrition, ill health, and chronic poverty. ${ }^{54}$ Before the latest border dispute resulted in the collective confinement of large numbers of Rohingya refugees, Rohingya children were left to wander the streets unaccompanied, which put them at considerable risk of abuse, including drug use, exploitation, and trafficking. Indeed, reports of Rohingya children in Malaysia ${ }^{55}$ and elsewhere demonstrate how such children may be "groomed for a life of abuse."

\section{The Obligation to Protect and the Right to Nationality}

The above case studies provide a brief illustration of forms of abuse that result from the deprivation of and the loss of a right to nationality. These include arbitrary expulsion, child exploitation in war, and the denial of the right to work, be educated, and secure decent housing. Although the states described vary in the degree to which they are party to particular human-rights instruments, they are all guilty of mistreatment of children by virtue of the prohibitions in international law described at the outset of this chapter. In this context, the academic distinction between state action where rights are denied (for example, cases where such children are deemed to be outside the polity) and situations where the rights of children are directly violated by states and third parties (for example, through expulsions and enlistment in armed units) is arguably of little legal value. It does, however, raise an important issue regarding membership and the effects of exclusion on the basis of nationality.

Status matters. In situations where stateless children had some formal status (for example, as refugees in one of the select camps in Bangladesh), they enjoyed considerably greater access to rights (education, health care, housing) than children without status. Having a recognized immigration 
and nationality status may determine whether one can access resources to address basic needs. Yet even in other situations (for example, in developed states such as the United Kingdom and Slovenia, where there is the added layer of European protection), status is essential to personal identity and security. The lack of formal status was a less predictable indicator of the personal fortunes of the Kashmiri children in the UK or the erased in Slovenia since some of the interviewees were able to enjoy education and had access to other rights before they turned eighteen, and some were able to remain in their country of residence after turning eighteen while others faced removal. Nonetheless, being legally stateless in Europe raised a number of fears and presented challenges that prevented young people from enjoying a reasonable quality of life. Above all, the arbitrariness of their situation and the inconsistent application of laws left them vulnerable to exploitation, psychological distress, and other illnesses.

For human-rights advocates, there are a number of conclusions to be drawn from the above discussion. The fact that some states may instigate abuse against children and create conditions of rightlessness requires further attention. As illustrated in the cases of the Rohingya in Myanmar and the erased in Slovenia, people who are excluded from censuses or deliberately removed from formal registers are susceptible to subsequent abuse on the grounds of nationality. The fact that legislation can be created subsequently (as in the Democratic Republic of the Congo and Slovenia) or applied retroactively (as in Myanmar) illustrates the fragility of nationality as a cornerstone of human-rights protection. As the above case studies demonstrate, nationality is a long-standing issue at the heart of geopolitical tensions and thus an issue that may be activated with potentially devastating human impacts during periods of political uncertainty.

\section{Conclusion}

The rights of children are among the most elaborated within contemporary international law. Children, however, may be exposed to gaps in the human-rights architecture regarding the implementation of such protection in the event that states do not recognize these rights under international law.

Unfortunately, neither the right to nationality nor many of the rights elaborated in the CRC and associated human-rights instruments are sufficient to prevent states from reinterpreting their obligations and deciding 
whom they should protect. Yet even though the right of children to a nationality is not sufficient to guarantee their protection from abuse by the state, respect for the right to nationality may nonetheless act as an important line of defense (for example, against expulsion, especially in the European context). Moreover, since nationality disputes may give rise to unrest and the violation of children's rights, as shown most emphatically in the Congolese case, it is essential that the protection of the right to nationality be considered a key element of conflict prevention. The mistreatment of minorities should send up early warning flags. To protect stateless children effectively, stringent efforts are required to shore up the right to nationality and to tie it more explicitly to widely accepted prohibitions against discrimination.

\section{Notes}

1. For a comprehensive review of the literature, see Brad K. Blitz, Statelessness, Protection, and Equality, UK Department of International Development and University of Oxford, Refugee Studies Centre Policy Brief, September 2009, $<$ http://www.rsc.ox.ac.uk> (accessed January 5, 2010).

2. International Court of Justice (ICJ), "Nationality Decrees Issued in Tunis and Morocco," Advisory Opinion no. 4, February 7, 1923, <http://www.unhcr.org> (accessed February 2, 2010).

3. League of Nations, Convention on Certain Questions Relating to the Conflict of Nationality Law, April 13, 1930, League of Nations, Treaty Series, vol. 179, p. 89, no. 4137, <http://www.unhcr.org> (accessed February 2, 2010).

4. UN General Assembly, "Universal Declaration of Human Rights," December 10, 1948, 217A(III), art. 15(2), <http://www.unhcr.org> (accessed February 2, 2010).

5. The Human Rights Committee has suggested that the concept of arbitrariness should be interpreted more broadly to include actions that might be described as "inappropriate" and "unjust" as well. For a good discussion on this point, see Open Society Justice Initiative, "Human Rights and Legal Identity: Approaches to Combating Statelessness and Arbitrary Deprivation of Nationality," paper presented at conference in New York, May 2006.

6. Examples acquiring by fraudulent means, voluntarily acquiring another nationality, or serving in a foreign military force. Other criteria that might be relied on include settlement in another country, no genuine link to the declared country or nationality that would support a claim to citizenship, and the placement of the national security or interests of a state at considerable risk.

7. The UN Committee on Economic, Social, and Cultural Rights' General Comment 4 makes a formal connection among survival, housing, and the preservation of cultural identities. See UN Committee on Economic, Social, and Cultural Rights (CESCR), "General Comment No. 4: The Right to Adequate 
Housing (Art. 11(1) of the Covenant)," December 13, 1991, E/1992/23, <http:// www.unhcr.org> (accessed February 2, 2010).

8. Under article 27, the Covenant declares that "In those States in which ethnic, religious or linguistic minorities exist, persons belonging to such minorities shall not be denied the right, in community with the other members of their group, to enjoy their own culture, to profess and practice their own religion, or to use their own language."

9. Although states may insist on language tests as a condition for the acquisition of citizenship, the article 27 affirms the rights of minorities to maintain and preserve their cultural identity and thus prohibits attempts to deny nationality on the grounds that minorities may speak another language or engage in different cultural practices.

10. See UN General Assembly, International Covenant on Economic, Social and Cultural Rights, December 16, 1966, A/RES/2200, art. 11(1), <http://www .unhcr.org > (accessed February 2, 2010).

11. For example, the nationality of married women and children is first mentioned in the 1930 Hague Convention on Certain Questions Relating to the Conflict of Nationality Laws under chapters III and IV, respectively. The rights of married women have been further elaborated in the 1957 Convention on the Nationality of Married Women. These principles are expressed even more strongly in article 9 of the 1979 Convention on the Elimination of All Forms of Discrimination against Women, December 18, 1979.

12. See David Weissbrodt, "Final Report on the Rights of Non-Citizens," UN Doc. E/CN.4/Sub.2/2003/23 UNHCR, 2003.

13. See UN Committee on the Elimination of Racial Discrimination (CERD), "CERD General Recommendation XXX on Discrimination against Non Citizens," October 1, 2002, <http://www.unhcr.org> (accessed February 2, 2010).

14. See "Concluding Observations of the Committee on the Elimination of Racial Discrimination: Mauritania,” CERD/C/65/CO/5, December 10, 2004, par. 18, <http://www.unhchr.ch> (accessed July 7, 2010).

15. See High Court (Botswana), Attorney General v. Unity Dow, CA No. 4/91, July 3, 1992, <http://www.law-lib.utoronto.ca> (accessed January 5, 2010).

16. UN High Commissioner for the Rights of Refugees (UNHCR), Statistical Online Population Database, 2009, <http://apps.who.int> (accessed January 5, 2010).

17. See, for example, the 2007 Still Human Still Here campaign by British NGOs, which highlighted the destitution of tens of thousands of refused asylum seekers in the United Kingdom, <http://stillhumanstillhere.wordpress.com> (accessed July 7, 2010).

18. See A. Bloch, "Refugee Settlement in Britain: The Impact of Policy on Participation," Journal of Ethnic and Migration Studies 26, no. 1 (2006): 75-88; J. A. Dennis, A Case for Change: How Refugee Children in England Are Missing Out (London: Children's Society, Refugee Council, and Save the Children, 2002); and R. Sales, "The Deserving and Undeserving? Refugees, Asylum Seekers and Welfare in Britain," Critical Social Policy 22, no. 3 (2002): 456-478. 
19. Sales, "The Deserving and Undeserving?"

20. In spite of large demonstrations in 2007, the State Assembly of the Jammu and Kashmir rejected a bill in May 2007 seeking to grant citizenship and other rights for the refugees of west Pakistan in the Jammu and Kashmir states.

21. Brad K. Blitz, "Statelessness and the Social (De)Construction of Citizenship: Political Restructuring and Ethnic Discrimination In Slovenia," Journal of Human Rights 5, no. 4 (2006): 1-27.

22. Ibid.

23. Jelka Zorn and rsula Lipovec ebron, Once upon an Erasure: From Citizens to Illegal Residents in the Republic of Slovenia (Ljubljana: Študentska Založba, 2008), <http://www.izbrisan17let.si> (accessed July 7, 2010).

24. J. Dedic, V. Jalušic, and J. Zorn, The Erased: Organized Innocence and the Politics of Exclusion (Ljubljana: Peace Institute, 2003).

25. Amnesty International, "Slovenia: Amnesty International's Briefing to the UN Committee on Economic, Social and Cultural Rights," 35th Session, November 2005 .

26. European Commission against Racism and Intolerance (ECRI), "Second Report on Slovenia, adopted 13 December 2002," Document CRI (2003), 39, July 8, 2003.

27. Matevz Krivic, interview with the author, June 9, 2004.

28. Helsinki Monitor of Slovenia, "Human Rights Problems in Slovenia," Statement No. 1, February 11, 1998, <http://www.fortunecity.com> (accessed January 5, 2010).

29. See Dedic, Jalušic, and Zorn, The Erased.

30. Focus group with author, June 14, 2004, Velenje, Slovenia.

31. Interview with Beslagic family, June 14, 2004, Velenje, Slovenia

32. Focus group, Ljubljana, June 10, 2004; Dragica Lukic, Bosnian Catholic (that is how she described herself).

33. B. Manby, Struggles for Citizenship in Africa (London: Zed Books, 2009), 8.

34. Equal Rights Trust, "Testimony of a Stateless Child in Detention in Egypt," Equal Rights Trust Review 3 (2009): 56-62.

35. Ibid., 57.

36. Les Forces Démocratiques de Libération du Rwanda (FDLR).

37. Human Rights Watch, "You Will Be Punished: Attacks on Civilians in Eastern Congo," Human Rights Watch (December 2009), <http://www.hrw.org> (accessed January 5, 2010).

38. Home Office, "Operational Guidance Note: Democratic Republic of Congo (DRC),” OGN V8.0, August 20, 2007, 12, <http://www.unhcr.org>.

39. See Manby, Struggles for Citizenship in Africa.

40. See Pax Christi International, "Human Insecurity in DRC: Examining the Causes and Effects," February 28, 2006, <http://storage.paxchristi.net> (accessed January 5, 2010). 
41. See UN General Assembly, "Children and Armed Conflict: Report of the Secretary-General," December 21, 2007, A/62/609-S/2007/757, <http://www .unhcr.org> (accessed February 2, 2010).

42. Human Rights Watch, "You Will Be Punished," 109.

43. Ibid., 93.

44. Amnesty International, "Perilous Plight: Burma's Rohingya Take to the Seas,” May 2009, <http://www.hrw.org> (accessed January 5, 2010).

45. C. Grundy-Warr and E. Wong, "Sanctuary under a Plastic Sheet: The Unresolved Problem of Rohingya Refugees," IBRU Boundary and Security Bulletin 5, no. 3 (Autumn 1997): 79-91.

46. Amnesty International, "Perilous Plight," 6.

47. Lawi Weng, "Rohingya Issue to Be Focus of Talks," The Irradwaddy, December 28, 2009, <http://www.irrawaddy.org> (accessed January 5, 2010).

48. Amnesty International, "Perilous Plight."

49. See Alex Ellgee, "The Vise Tightens on Rohingya in Bangladesh," The Irrawaddy, November 7, 2009, <http://www.irrawaddy.org>.

50. See Weng, "Rohingya Issue to Be Focus of Talks."

51. Commission of the European Communities, "Commission Decision on the Financing of Emergency Humanitarian Actions from the General Budget of the European Communities in Bangladesh," ECHO/BGD/BUD/2009/02000, <http:// ec.europa.eu> (accessed January 5, 2010).

52. Ibid.

53. Commission of the European Communities, "Commission Decision," 2.

54. Ibid.

55. J. Allchin, "Rohingya Children Groomed for a Life of Abuse," Democratic Voice of Burma, November 4, 2009, <http://english.dvb.no> (accessed January 5, 2010). 